\title{
Size of plots for experiments with cactus pear cv. Gigante
}

\author{
Bruno V. C. Guimarães ${ }^{1}$, Sérgio L. R. Donato ${ }^{2}$, Ignacio Aspiazú ${ }^{3}$, \\ Alcinei M. Azevedo ${ }^{4} \&$ Abner J. de Carvalho ${ }^{3}$
}

\begin{abstract}
${ }^{1}$ Instituto Federal do Amazonas/Departamento de Ciências Agrárias. São Gabriel da Cachoeira, AM, Brasil. E-mail: bvinicius20@yahoo.com.br (Corresponding author) - ORCID: 0000-0003-2585-8794

${ }^{2}$ Instituto Federal Baiano/Departamento de Ciências Agrárias. Guanambi, BA, Brasil. E-mail: sergio.donato@ifbaiano.edu.br - ORCID: 0000-0002-7719-4662

${ }^{3}$ Universidade Estadual de Montes Claros/Departamento de Ciências Agrárias. Janaúba, MG, Brasil. E-mail: ignacio.aspiazu@unimontes.br - ORCID: 0000-0002-0042-3324; abner.carvalho@unimontes.br - ORCID: 0000-0002-6644-5307

${ }^{4}$ Universidade Federal de Minas Gerais/Instituto de Ciências Agrárias. Montes Claros, MG, Brasil. E-mail: alcineimistico@hotmail.com - ORCID: 00000001-5196-0851
\end{abstract}

\begin{abstract}
The definition of experimental plot size is an essential tool to ensure precision in statistical analysis in experiments. The objective of this study was to estimate the plot size for the cactus pear cv. Gigante using the Modified Maximum Curvature Method, under the semi-arid conditions of Northeastern Brazil. The uniformity test was conducted at the Federal Institute of Bahia, Guanambi Campus, Bahia state, Brazil, during the agricultural period from 2009 to 2011 . The spatial arrangement was composed of ten rows with 50 plants each, whose evaluated area was formed by the eight central rows with 48 plants per row, making 384 plants and area of $153.60 \mathrm{~m}^{2}$. The following variables were evaluated: plant height; length, width and thickness of cladode; number of cladodes; total area of cladodes; cladode area and green mass yield in the third production cycle. In the evaluations, each plant was considered as a basic experimental unit (BEU), with an area of 0.4 $\mathrm{m}^{2}$, comprising 384 basic units (BU), whose adjacent ones were combined to form 15 pre-established plot sizes with rectangular shapes and in rows. The characteristics total area of cladodes and green mass yield require larger plot sizes to be evaluated with greater experimental accuracy. For experimental evaluation of cactus pear cv. Gigante, plot size should be eight plants in the direction of the crop row.
\end{abstract}

Key words: uniformity, descriptors, Opuntia ficus-indica

\section{Tamanho de parcelas para experimentos com palma forrageira cv. Gigante}

RESUMO: A definição do tamanho da parcela experimental configura-se como ferramenta essencial para assegurar a precisão na análise estatística em experimentos. Assim objetivou-se estimar o tamanho de parcela para a cultura da palma forrageira cv. Gigante por meio do Método da Máxima Curvatura Modificado, nas condições do Semiárido Nordestino. O ensaio de uniformidade foi conduzido no Instituto Federal Baiano, Campus Guanambi, Bahia, Brasil, no período agrícola de 2009 a 2011. O arranjo espacial foi composto por dez fileiras com 50 plantas cada, cuja área útil foi formada pelas oito fileiras centrais com 48 plantas por fileira, perfazendo 384 plantas e área de 153,60 $\mathrm{m}^{2}$. Foram avaliadas as variáveis altura da planta; comprimento, largura e espessura do cladódio; número de cladódios; área total do cladódio; área do cladódio e a produtividade de massa verde no terceiro ciclo de produção. Nas avaliações, cada planta foi considerada como uma unidade experimental básica (UEB), com área de $0,4 \mathrm{~m}^{2}$, contemplando 384 unidades básicas (UB), cujas adjacentes foram combinadas de modo a formar 15 tamanhos de parcelas pré-estabelecidos com formatos retangulares e em fileiras. As características área total do cladódio e produtividade de massa verde exigem maiores tamanhos de parcela para serem avaliadas com maior precisão experimental. Para avaliação experimental da palma forrageira cv. Gigante, o tamanho de parcela deve ser de oito plantas no sentido da fileira de cultivo.

Palavras-chave: uniformidade, descritores, Opuntia ficus-indica 


\section{INTRODUCTION}

Cactus pear (Opuntia ficus-indica Mill.) cultivation has expanded in Brazil, especially due to the wide use of this cactus species as animal feed (Aguiar et al., 2015). In Northeast Brazil, the plant is considered as source of energy with great potential in the nutrition of ruminants and, recently, the State of Bahia has intensified the efforts towards research and production of cactus pear (Padilha Junior et al., 2016; Silva et al., 2016; Donato et al., 2017).

However, studies on this forage crop, besides presenting different experimental sizes, show oversized plots, usually defined by the experience of the researcher, based on the available resources and/or on the dimension of the experimental area (Padilha Junior et al., 2016; Silva et al., 2016; Donato et al., 2016, 2017), which justifies the need for adequate statistical planning.

The maximum modified curvature method (MMCM), through a regression equation, algebraically determines the optimal point of the plot size using the relationship between the coefficients of variation and its respective sizes (Pereira et al., 2017). With this model it is possible to minimize experimental error, optimize resources and ensure maximum precision (Cargnelutti Filho et al., 2018).

Cactus pear cv. Gigante, for being a typical cactus species, has spines in its morphological structure, which causes the researcher to work without ergonomics and sometimes under insalubrious conditions. That, associated with the exposure to full sun, aggravates the difficulties in evaluating the crop. Thus, besides the statistical significance, adequate sizes of experimental plots ensure practical viability of sampling and precision in data collection (Sousa et al., 2016).

Despite that, there are no studies in the literature on estimates of size and shape of experimental plots to evaluate phenotypic descriptors in cactus pear. Therefore, this study aimed to evaluate the optimal plot size for cactus pear cv. Gigante, under the semi-arid conditions of Northeast of Brazil.

\section{Material And Methods}

The study was carried out at the Federal Institute of Education, Science and Technology of Bahia, Campus of Guanambi-BA, Brazil, in the period from 2009 to 2011. The experimental field is located in the district of Ceraíma (14 ${ }^{\circ}$ $13^{\prime} 30^{\prime \prime} \mathrm{S}, 42^{\circ} 46^{\prime} 53^{\prime \prime} \mathrm{W}$ and altitude of $525 \mathrm{~m}$ ). The region is characterized by a hot tropical semi-arid climate (Köppen), with mean annual rainfall and temperature of $670.2 \mathrm{~mm}$ and $25.9{ }^{\circ} \mathrm{C}$, respectively. The soil of the experimental area was classified as Litholic Neosol (EMBRAPA, 2013).

Uniformity test with cactus pear cv. Gigante was conducted by adopting homogeneous cultivation practices in the entire area, as recommended by Ramalho et al. (2012). Cladodes, properly prepared for planting with 15-day curing, were planted in October 2009 at $2 \times 0.2 \mathrm{~m}$ spacing, and each plant was considered as one basic experimental unit (BEU). The spatial arrangement comprised ten rows of 50 plants each. The evaluated area was formed by the eight central rows and 48 plants per row, disregarding the plants on each end, that is, a total of 384 plants and an area of $153.60 \mathrm{~m}^{2}$.

The variables plant height $(\mathrm{PH}-\mathrm{m})$; length $(\mathrm{CL}-\mathrm{cm})$, width $(\mathrm{CW}-\mathrm{cm})$ and thickness (CT - mm) of cladode; number of cladodes (NC); total area of cladodes (TAC $-\mathrm{cm}^{2}$ ); cladode area $\left(\mathrm{CA}-\mathrm{cm}^{2}\right)$ and cladode green mass yield $\left(\mathrm{Y}-\mathrm{Mg} \mathrm{ha}^{-1}\right)$ were evaluated in the third production cycle, at 930 days after planting.

To simulate the 15 plot sizes, adjacent BEUs were combined to form rectangular plots along the crop row direction (Table 1).

The modified maximum curvature method (Lessman \& Atkins, 1963), adapted by Meier \& Lessman (1971), was used to algebraically estimate the point at which the curvature is maximal, which corresponds to the optimal plot size, by the exponential regression equation Eq. 1:

$$
y=\frac{a}{x^{b}}
$$

where:

y - indicates the coefficient of variation;

$\mathrm{x}$ - represents plot size in basic units; and,

$\mathrm{a}$ and $\mathrm{b}$ - constants suitable for the model.

The maximum curvature point was given by Eq. 2 :

$$
\mathrm{XMC}=\left[\frac{\hat{\mathrm{A}}^{2} \hat{\mathrm{B}}^{2}(2 \hat{\mathrm{B}}+1)}{\hat{\mathrm{B}}+2}\right]^{\frac{1}{(2+2 \mathrm{~B})}}
$$

\begin{tabular}{|c|c|c|c|c|c|c|c|c|}
\hline \multirow{2}{*}{ Identification } & \multirow{2}{*}{ Number of plots } & \multirow{2}{*}{ Shape } & \multirow{2}{*}{ Row } & \multirow{2}{*}{ Plants row ${ }^{-1}$} & \multicolumn{2}{|c|}{ Dimensions (m) } & \multirow{2}{*}{$\begin{array}{l}\text { Number } \\
\text { of BEU }\end{array}$} & \multirow{2}{*}{$\begin{array}{l}\text { Area } \\
\left(\mathrm{m}^{2}\right)\end{array}$} \\
\hline & & & & & Width & Length & & \\
\hline A & 2 & Rectangular & 4 & 48 & 8 & 9.6 & 192 & 76.80 \\
\hline B & 3 & Rectangular & 8 & 16 & 16 & 3.2 & 128 & 51.20 \\
\hline C & 4 & Rectangular & 8 & 12 & 16 & 2.4 & 96 & 38.40 \\
\hline D & 6 & Rectangular & 8 & 8 & 16 & 1.6 & 64 & 25.60 \\
\hline $\mathrm{E}$ & 8 & Rectangular & 4 & 12 & 8 & 2.4 & 48 & 19.20 \\
\hline $\mathrm{F}$ & 12 & Rectangular & 8 & 4 & 16 & 0.8 & 32 & 12.80 \\
\hline G & 16 & Rectangular & 2 & 12 & 4 & 2.4 & 24 & 9.60 \\
\hline $\mathrm{H}$ & 24 & Rectangular & 4 & 4 & 8 & 0.8 & 16 & 6.40 \\
\hline I & 32 & Rectangular & 1 & 12 & 2 & 2.4 & 12 & 4.80 \\
\hline J & 48 & Row & 8 & 1 & 16 & 0.2 & 8 & 3.20 \\
\hline K & 64 & Row & 1 & 6 & 2 & 1.2 & 6 & 2.40 \\
\hline L & 96 & Row & 1 & 4 & 2 & 0.8 & 4 & 1.60 \\
\hline$M$ & 128 & Row & 1 & 3 & 2 & 0.6 & 3 & 1.20 \\
\hline $\mathrm{N}$ & 192 & Row & 1 & 2 & 2 & 0.4 & 2 & 0.80 \\
\hline 0 & 384 & Row & 1 & 1 & 2 & 0.2 & 1 & 0.40 \\
\hline
\end{tabular}

Table 1. Number and shape of plots, number of rows and plants per row, number of basic units and total area of the plot

BEU - Basic experimental unit 
where:

$\mathrm{XMC}$ - X-axis value corresponding to the maximum curvature point, i.e., it is the estimator of optimal plot size; and,

$\hat{\mathrm{A}}$ and $\hat{\mathrm{B}}$ - respective estimates of $\mathrm{A}$ and $\mathrm{B}$, constants suitable for the equation.

Considering that the maximum curvature point $\mathrm{XMC}$ is defined as critical point of plot, Lúcio et al. (2012) argue that decimal transformation of this value must meet the criteria of the discrete variables with approximation to the immediately superior integer.

Statistical determinations to estimate plot size using the modified maximum curvature method were conducted in the calculation program Excel ${ }^{\circ}$ from Microsoft.

\section{Results AND Discussion}

In the formation of the 15 plots with different sizes, there was a statistical trend of exponential model for the standard deviation $\left(S=6.0285 \mathrm{x}^{0.5365} ; \mathrm{R}^{2}=0.9677\right)$ and linear increase for the mean $\left(m=12.351 X-0.0023 ; R^{2}=1\right)$, with increment in the sizes of BEUs (X, in BEU) (Table 2).

Lowest and highest experimental coefficients of variation (ECV) were respectively associated with combinations of highest and lowest numbers of BEUs (Table 2), as expected, because increment in plot sizes usually reduces ECV, except under conditions of heterogeneous soils, in which larger plots may express higher ECV, in response to the soil heterogeneity index (Donato et al., 2018).

In agricultural experimentation, ECV reflects experimental precision, and plot shapes with lower estimates of this parameter are highly precise (Cargnelutti Filho et al., 2018). The relation between plot size (BEU) and ECV (Table 2) can be explained by an exponential regression equation, $\mathrm{ECV}=49.028 \mathrm{x}^{-0.468} ; \mathrm{R}^{2}=0.9557$. Nonlinear reduction of $\mathrm{ECV}$ is commonly associated with BEU size both in width and length, and such inverse relation between the statistical parameters has been corroborated by several studies (Santos et al., 2015; Brum et al., 2016; Sousa et al., 2016; Cargnelutti Filho et al., 2018).

Figure 1 represents the relation between ECV and plot size in BEU. The maximum curvature point with highest estimate for the characteristics evaluated was associated with total area of cladodes (Figure 1B), followed by green mass yield (Figure 1D) with approximate plot sizes of seven and eight BEUs, respectively.

Determination coefficients ranged from 0.8082 (Figure 1F) to 0.9352 (Figure 1D) for the vegetative variables of cactus pear evaluated in the third production cycle. These estimates express adequate precision in the fitting of the models.

Santos et al. (2015) simulated plot sizes for different hybrids of sunflower using modified maximum curvature method (MMCM) and obtained similar fits to those of the present study, with $\mathrm{R}^{2}$ between 0.8806 and 0.9648 for the optimal plot sizes. With this same estimator, $\mathrm{R}^{2}$, Cargnelutti Filho et al. (2018) identified the optimal plot size (XMC, in $\mathrm{m}^{2}$ ), with fit of 0.9989 to evaluate the fresh mass of forage turnip.

Optimal plot sizes varied according to the evaluated characteristics, with XMC and X estimates between 2.14 and 7.72 and three and eight BEUs, respectively (Figure 1). The MMCM, besides estimating the optimal plot size preestablished by the critical point, also presents intermediate sizes among those tested, as observed in several studies (Cargnelutti Filho et al., 2014; Santos et al., 2015; Guarçoni et al., 2017).

However, when optimal plot size is achieved the continuous reduction of ECV leads to no gains in experimental precision because, from the critical or maximum curvature point, ECV tends to stability (Santos et al., 2015).

Plots with discrepant sizes to the critical point lead to limited gains of precision, with higher experimental costs and greater demand for human resources, besides the possibility of incurring results outside the statistical bias (Cargnelutti Filho et al., 2018). Thus, plots with practical size of three to eight BEUs were estimated, which favors decision-making with respect to precise experimental planning and adequate direction for the agronomic characteristics to be investigated.

Despite that, the largest plot size, eight BEU, must be considered for the evaluated characteristics because the characteristics observed in the study are normally evaluated together. Therefore, the largest size is selected - indicated by the characteristic with highest variability. Thus, all characteristics analysed are met. In addition, it is justifiable to adopt this procedure because the MCMM, despite its easy application and for being of algebraic determination (Cargnelutti Filho

Table 2. Number of plots (NP), with sizes [rows $(\mathrm{Xr}) \times$ plants per rows $\left(\mathrm{Xpr}^{-1}\right)$ ], basic experimental units (BEUs), area and respective estimates of mean, variance $\left(\mathrm{s}^{2}\right)$, standard deviation $(\mathrm{SD})$ and experimental coefficient of variation (ECV) for evaluation of yield of cactus pear cv. Gigante in uniformity test with 384 BEUs of $2 \times 0.2 \mathrm{~m}\left(0.4 \mathrm{~m}^{2}\right)$

\begin{tabular}{|c|c|c|c|c|c|c|c|c|}
\hline NP & $X_{r}$ & $\mathrm{Xpr}^{-1}$ & BEUs & $\begin{array}{r}\text { Area } \\
\left(m^{2}\right)\end{array}$ & $\begin{array}{c}\text { Mean } \\
\left(\mathrm{kg} \mathrm{plot}^{-1}\right)\end{array}$ & $\$^{2}$ & $\begin{array}{c}\text { SD } \\
\left(\mathrm{kg} \mathrm{plot}^{-1}\right)\end{array}$ & $\begin{array}{l}\text { ECV } \\
(\%)\end{array}$ \\
\hline 2 & 4 & 48 & 192 & 76.8 & 2371.45 & 8698.80 & 93.26 & 3.93 \\
\hline 3 & 8 & 16 & 128 & 51.2 & 1580.97 & 7543.36 & 86.85 & 5.49 \\
\hline 4 & 8 & 12 & 96 & 38.4 & 1185.73 & 5169.95 & 71.90 & 6.06 \\
\hline 6 & 4 & 16 & 64 & 25.6 & 790.48 & 2888.75 & 48.15 & 6.09 \\
\hline 8 & 4 & 12 & 48 & 19.2 & 592.86 & 1824.10 & 42.70 & 7.20 \\
\hline 12 & 4 & 8 & 32 & 12.8 & 395.24 & 1102.24 & 33.20 & 8.40 \\
\hline 16 & 2 & 12 & 24 & 9.6 & 296.43 & 2669.21 & 51.66 & 17.43 \\
\hline 24 & 4 & 4 & 16 & 6.4 & 197.62 & 487.83 & 22.08 & 11.18 \\
\hline 32 & 1 & 12 & 12 & 4.8 & 148.21 & 792.86 & 28.15 & 18.99 \\
\hline 48 & 4 & 2 & 8 & 3.2 & 98.81 & 282.58 & 16.81 & 17.01 \\
\hline 64 & 1 & 6 & 6 & 2.4 & 74.11 & 268.79 & 16.39 & 22.12 \\
\hline 96 & 1 & 4 & 4 & 1.6 & 49.40 & 149.21 & 12.21 & 24.72 \\
\hline 128 & 1 & 3 & 3 & 1.2 & 37.05 & 107.26 & 10.35 & 27.94 \\
\hline 192 & 1 & 2 & 2 & 0.8 & 24.70 & 69.66 & 8.34 & 33.78 \\
\hline 384 & 1 & 1 & 1 & 0.4 & 12.35 & 38.02 & 6.17 & 49.92 \\
\hline
\end{tabular}




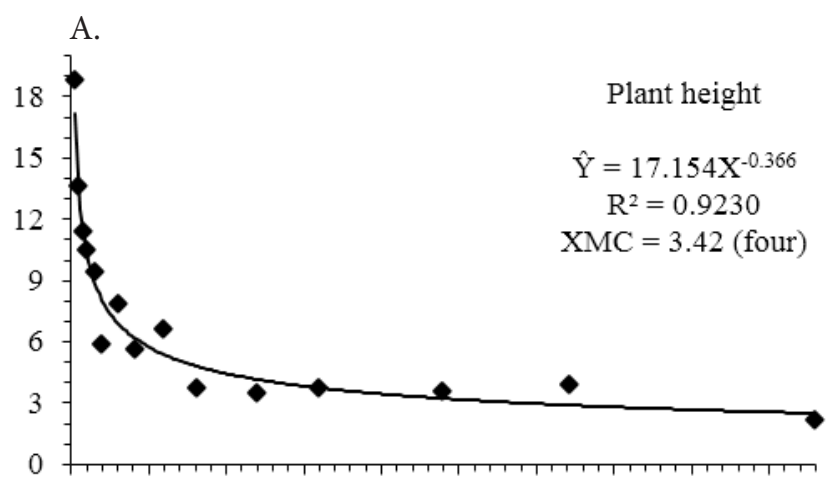

C.
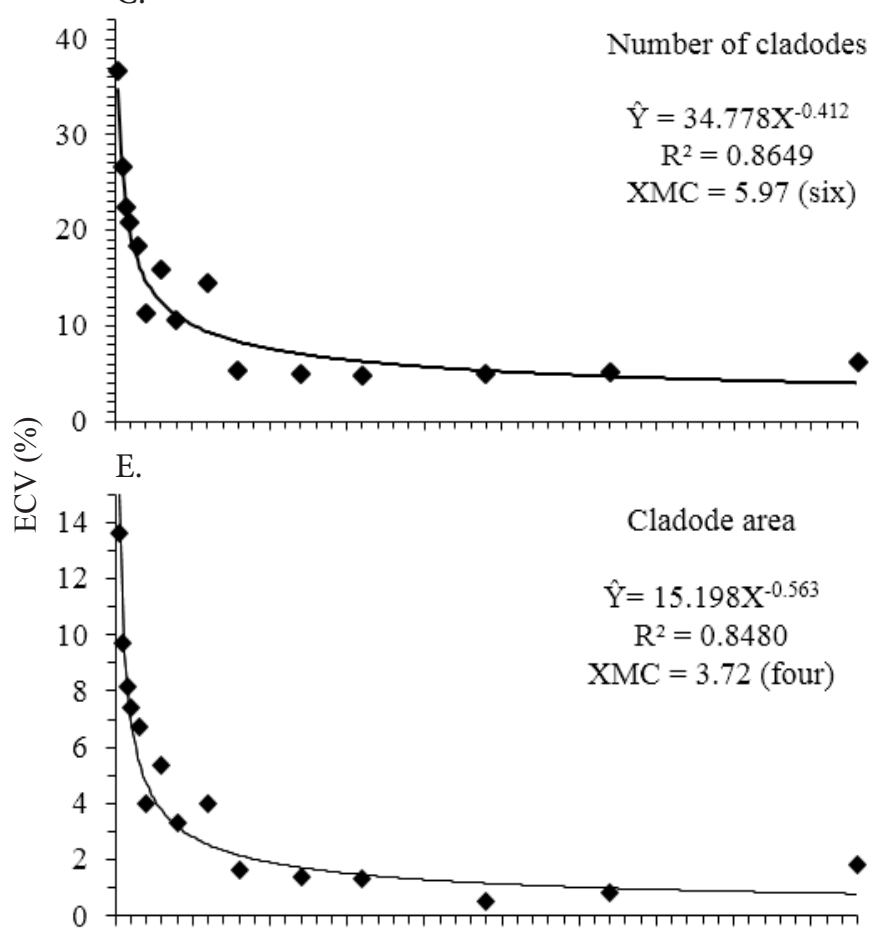

G.

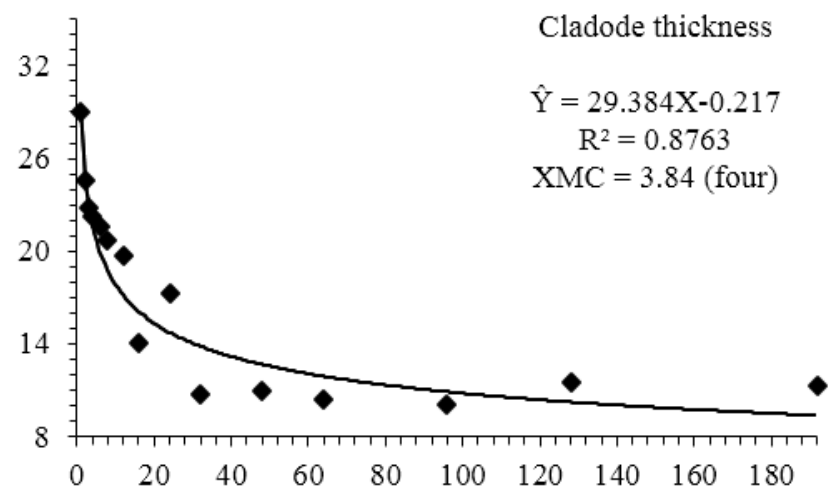

B.

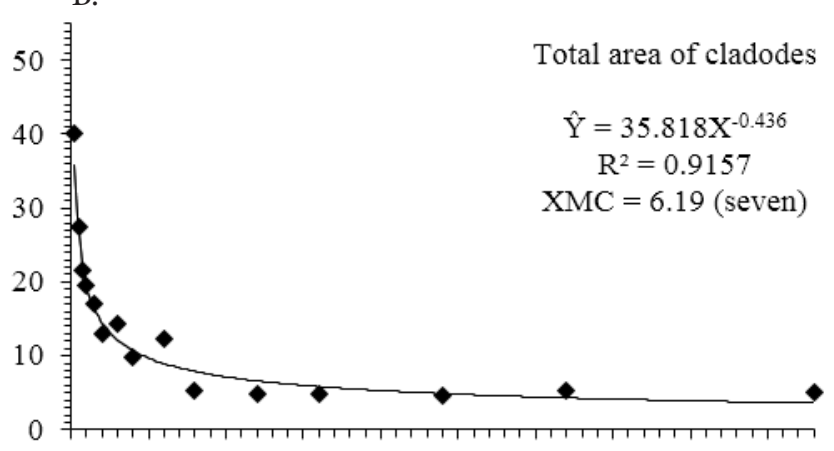

D.

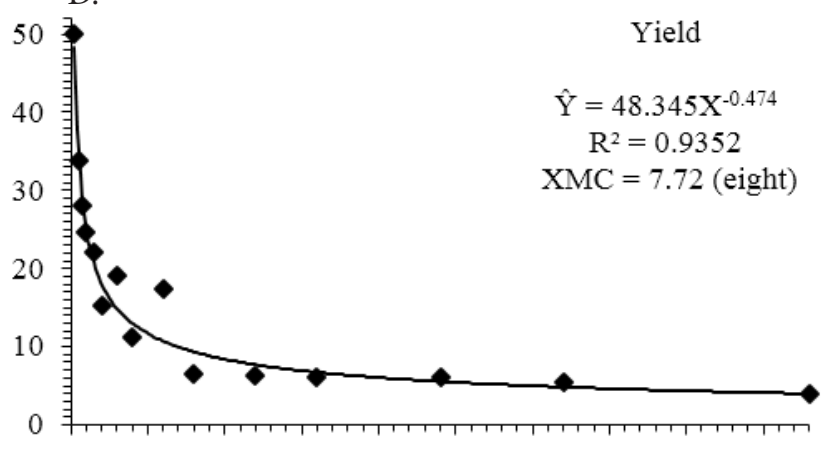

$\mathrm{F}$.

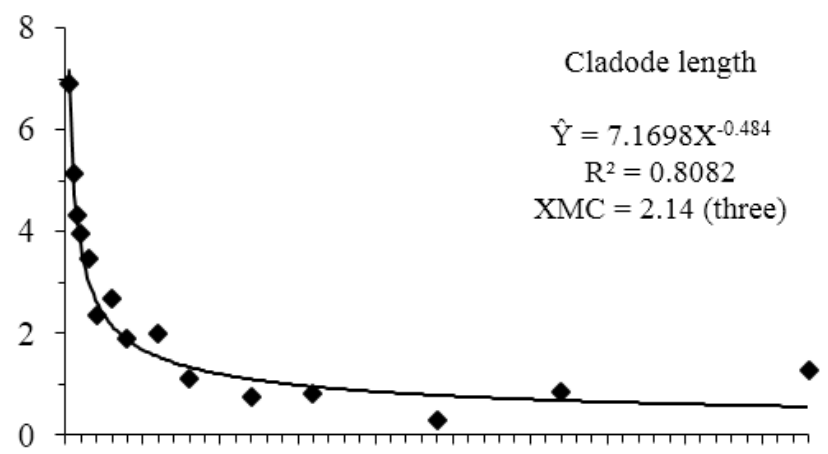

$\mathrm{H}$.

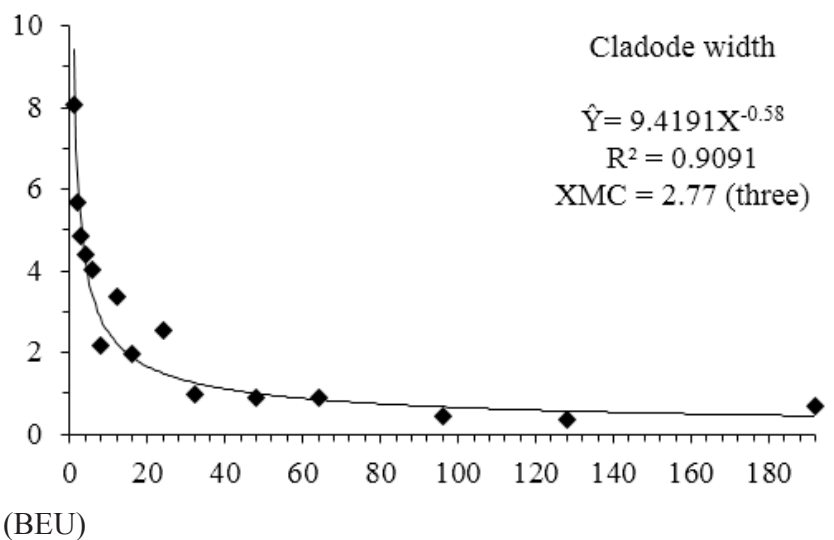

Figure 1. Relation between experimental coefficient of variation (ECV) and plot size in basic experimental unit (BEU) for the estimate of maximum curvature (XMC) of the variables plant height (A), total area of cladodes (B), number of cladodes (C), yield (D), cladode area (E), cladode length (F), cladode thickness $(G)$ and cladode width (H) of cactus pear

et al., 2016), tends to determine smaller plot sizes compared to other methods (Donato et al., 2008).

\section{Conclusions}

1. The characteristics total area of cladodes and green mass yield require larger plot sizes to be evaluated with higher experimental precision.
2. For experimental evaluation of cactus pear cv. Gigante, plot size should be eight plants in the crop row direction.

\section{ACKNOWLeDgments}

To the Federal Institutes: Instituto Federal do Amazonas (IFAM) and Instituto Federal Baiano (IF-Baiano) and to the Universidade Estadual de Montes Claros (UNIMONTES). 
The present study was conducted with support from the Coordenação de Aperfeiçoamento de Pessoal de Nível Superior (CAPES, Brazil) - Finance Code 001.

\section{Literature Cited}

Aguiar, M. do S. M. A.; Silva, F. F. da; Donato, S. L. R.; Schio, A. R.; Souza, D. D. de; Meneses, M. de A.; Lédo, A. A. Síntese de proteína microbiana e concentração de ureia em novilhas leiteiras alimentadas com palma forrageira Opuntia. Semina: Ciências Agrárias, v.36, p.999-1012, 2015. https://doi.org/10.5433/16790359.2015v36n2p999

Brum, B.; Brandelero, F. D.; Vargas, T. de O.; Storck, L.; Zanini, P. P. G. Tamanho ótimo de parcela para avaliação da massa e diâmetro de cabeças de brócolis. Ciência Rural, v.46, p.447-463, 2016. https:// doi.org/10.1590/0103-8478cr20150236

Cargnelutti Filho, A.; Araujo, M. M.; Gasparin, E.; Foltz, D. R. B. Dimensionamento amostral para avaliação de altura e diâmetro de plantas de timbaúva. Floresta e Ambiente, v.25, p.1-9, 2018.

Cargnelutti Filho, A.; Storck, L.; Lúcio, A. D.; Toebe, M.; Alves, B. M. Tamanho de unidades experimentais básicas e tamanho ótimo de parcelas para nabo-forrageiro. Pesquisa Agropecuária Brasileira, v.51, p.309-319, 2016. https://doi.org/10.1590/S0100204X2016000400003

Cargnelutti Filho, A.; Toebe, M.; Burin, C.; Casarotto, G.; Alves, B. M. Planejamentos experimentais em nabo-forrageiro semeado a lanço e em linha. Bioscience Journal, v.30, p.677-686, 2014.

Donato, P. E. R.; Donato, S. L. R.; Silva, J. A.; Pires, A. J. V.; Rosa, R. C. C.; Aquino, A. A. Nutrition and yield of 'Gigante' cactus pear cultivated with different spacings and organic fertilizer. Revista Brasileira de Engenharia Agrícola e Ambiental, v.20, p.1083-1088, 2016. https://doi.org/10.1590/1807-1929/agriambi. v20n 12 p1083-1088

Donato, P. E. R.; Donato, S. L. R.; Silva, J. A.; Pires, A. J. V.; Silva Júnior, A. A. e. Extraction/exportation of macronutrients by cladodes of 'Gigante' cactus pear under different spacing and organic fertilization. Revista Brasileira de Engenharia Agrícola e Ambiental, v.21, p.238-243, 2017. https://doi.org/10.1590/18071929/agriambi.v21n4p238-243

Donato, S. L. R.; Silva, J. A. da; Guimarães, B. V. C.; Silva, S. de O. e. Experimental planning for the evaluation of phenotipic descriptors in banana. Revista Brasileira de Fruticultura, v.40, p.1-13, 2018. https://doi.org/10.1590/0100-29452018962

Donato, S. L. R.; Siqueira, D. L. de; Silva, S. de O. e; Cecon, P. R.; Silva, J. A. da; Salomão, L. C. C. Estimativas de tamanho de parcelas para avaliação de descritores fenotípicos em bananeira. Pesquisa Agropecuária Brasileira, v.43, p.957-969, 2008. https:// doi.org/10.1590/S0100-204X2008000800003
EMBRAPA - Empresa Brasileira de Pesquisa Agropecuária. Sistema brasileiro de classificação de solos. 3.ed. Brasília: Embrapa Informação Tecnológica, 2013. 353p.

Guarçoni, R. C.; Souza, J. L. de; Favarato, L. F.; Angeletti, M. da P.; Bahiense, D. V. Determinação do tamanho ótimo de parcela experimental para experimentos com repolho utilizando simulação e métodos de estimação. Revista Científica Intelletto, v.2, p.79-87, 2017. https://doi.org/10.17648/intelletto-2525-9075-v2-n2-09

Lessman, K. J.; Atkins, R. E. Optimum plot size and relative efficiency of lattice designs for grain sorghum yield test. Crop Science, v.3, p.477-481, 1963. https://doi.org/10.2135/ cropsci1963.0011183X000300060006x

Lúcio, A. D.; Haesbaert, F. M.; Santos, D.; Schwertner, D. V.; Brunes, R. R. Tamanhos de amostras e de parcelas para variáveis de crescimento e produtivas de tomateiro. Horticultura Brasileira, v.30, p.660-668, 2012. https://doi.org/10.1590/S010205362012000400016

Meier, V. D.; Lessman, K. J. Estimation of optimum field plot shape and size for testing yield in Crambe abyssinica hordnt. Crop Science, v.11, p.648-650, 1971. https://doi.org/10.2135/ cropsci1971.0011183X001100050013x

Padilha Junior, M. C.; Donato, S. L. R.; Silva, J. A. da; Donato, P. E. R.; Souza, E. dos S. Características morfométricas e rendimento da palma forrageira 'Gigante' sob diferentes adubações e configurações de plantio. Revista Verde de Agroecologia e Desenvolvimento Sustentável, v.11, p.67-72, 2016. https://doi. org/10.18378/rvads.v11i1.3710

Pereira, A. S.; Silva, G. O.; Carvalho, A. D. F. Minimum plot size to evaluate potato tuber yield traits. Horticultura Brasileira, v.35, p.604-608, 2017. https://doi.org/10.1590/s0102-05362017042020

Ramalho, M. A. P.; Ferreira, D. F.; Oliveira, A. C. de. Experimentação em genética e melhoramento de plantas. Lavras: Editora da UFLA, 2012. 305p.

Santos, A. M. P. B. dos; Peixoto, C. P.; Almeida, A. T.; Santos, J. M. da S. dos; Machado, G. da S. Tamanho ótimo de parcela para a cultura de girassol em três arranjos espaciais de plantas. Revista Caatinga, v.28, p.265-273, 2015. https://doi.org/10.1590/198321252015v28n430rc

Silva, J. A. da; Donato, S. L. R.; Donato, P. E. R.; Souza, E. dos S.; Padilha Junior, M. C.; Silva Junior, A. A. e. Extraction/export of nutrients in Opuntia ficus-indica under different spacings and chemical fertilizers. Revista Brasileira de Engenharia Agrícola e Ambiental, v.20, p.236-242, 2016. https://doi.org/10.1590/18071929/agriambi.v20n3p236-242

Sousa, R. P. de; Silva, P. S. L. e; Assis, J. P. de. Tamanho e forma de parcelas para experimentos com girassol. Revista Ciência Agronômica, v.47, p.683-690, 2016. https://doi.org/10.5935/18066690.20160082 